\title{
Raillietiella gigliolii (PENTASTOMIDA) INFECTING Amphisbaena alba (SQUAMATA, AMPHISBAENIDAE): THE FIRST RECORD FOR NORTHEAST BRAZIL
}

\author{
ALMEIDA, W. O. ${ }^{1}$, FERREIRA, F. S. ${ }^{1}$, BRITO, S. V. ${ }^{1}$ and CHRISTOFFERSEN, M. L. ${ }^{2}$ \\ ${ }^{1}$ Departamento de Ciências Físicas e Biológicas, Universidade Regional do Cariri, Crato, CE, Brazil \\ ${ }^{2}$ Departamento de Sistemática e Ecologia, Universidade Federal da Paraíba, CCEN, João Pessoa, PB, Brazil \\ Correspondence to: Waltécio de Oliveira Almeida, Departamento de Ciências Físicas e Biológicas, \\ Universidade Regional do Cariri - URCA/CE, Campus do Pimenta, Rua Cel. Antônio Luiz, 1161, \\ CEP 63105-000, Crato, CE, Brazil, e-mail: walmeida@urca.br \\ Received March 30, 2005 - Accepted July 5, 2005 - Distributed November 1, 2006
}

(With 1 figure)

The Raillietiellidae family is represented by the single pentastomid genus Raillietiella. There are records of parasitism for toads, lizards, serpents and amphisbaenids, showing evidence that there is quite a diversity of hosts (Almeida \& Christoffersen, 1999, 2002). According to Almeida \& Christoffersen (1999), Raillietiellidae is the sister group of the Cephalobaenidae and Reighardiidae families, representing the most basal clade of Pentastomida.

Circa 42 species of raillietiellids have been described. As general characters they present a cylindrical body, hooks forming a trapezoid design, parapodia present, rostrum reduced, cirri short, and fulcrum proportional to the size of the hooks (Riley, 1986; Almeida \& Christoffersen, 1999, 2002).

Species of raillietiellids occurring in Brazil are (i) Raillietiella freitasi (Motta \& Gomes, 1968), (ii) R. furcocerca (Diesing, 1863), and (iii) R. gigliolii Hett, 1924.

The latest citations of raillietiellids in Brazil were provided by Motta \& Gomes (1968), Rego (1983), Vrcibradic et al. (2002) and Dias et al. (2005). Motta \& Gomes (1968) registered the occurrence of $R$. freitasi in the lungs of Mabuya punctata (Spix, 1825) and Bufo paracnemis Lutz, 1925. Rego (1983) found R. gigliolii in the respiratory tract of Amphisbaena alba Linnaeus, 1758 and $R$. furcocerca infecting Drymarchon corais (Boie, 1827), Xenodon merremii (Wagler, 1824) and Lachesis sp. Vrcibradic et al. (2002) described Raillitiella sp. as parasitizing Mabuya agilis (Raddi, 1823). Dias et al. (2005) quote the presence of Railleitiella aff. furcocerca in the community study of helminths of Cnemidophorus abaetensis Dias et al., 2002 and C. ocellifer (Spix, 1825). The only citations of raillietiellids for the northeast region of Brazil were provided by Motta \& Gomes (1968) and by Dias et al. (2005), who studied material from Fernando de Noronha Island and the State of Bahia, respectively.

Amphisbaenids were collected between January and August, 2004 in two sites at the Floresta Nacional do Araripe (FLONA) $\left(07^{\circ} 16^{\prime} \mathrm{S}\right.$ and $39^{\circ} 26^{\prime} \mathrm{W}$ ), a protected environmental area of the 'IBAMA - Institute for the Environment and Natural Resources', municipality of Crato, State of Ceará, Northeast Brazil. The amphisbaenids were captured by using the classical herpetological methods of active patterned collecting (Vanzolini \& Papavero, 1967; Auricchio \& Salomão, 2002). After collection, the amphisbaenids were euthanised with ether, fixed and preserved in ethanol 70\%. They were subsequently identified according to BarrosFilho \& Valverde (1996) and Vanzolini (2002). The snout-vent length (SVL) was measured in each specimen using a caliper in centimeters.

The respiratory tracts of the amphisbaenids were removed and pentastomids were searched for under a stereomicroscope. The pentastomids that were found were cleared in the Hoyer's medium and slide-mounted. Identification followed on the basis of the dimensions of the hooks in males and copulatory spicule by using a microscope with micrometric ocular (see Ali et al. 1984, 1985). A figure was made with a drawing tube connected to a brightfield microscope. The eco-parasitological terms used followed Bush et al. (1997). 
A total of three female specimens of Amphisbaena alba (SVL range 29-82 cm) were collected and deposited in the collection of the Coleção do Laboratório de Zoologia da Universidade Regional do Cariri (LZ-URCA 0021, 0022, 0023). Among the three specimens of $A$. alba which were analysed, one presented three male specimens of Raillietiella gigliolii (LZURCA 0099, 0100, 0101) infecting the respiratory tract. This is the first record of $R$. gigliolii for the northeast region of Brazil. The infection patterns had a prevalence of $33.3 \%$ and mean intensity of $3.0 \pm 0.0(\mathrm{~s}=3)$.

The raillietiellids encountered were characterized as adult specimens on the basis of their simple hooks. Nymphs are characterized by the presence of double hooks with chitinous accessory structures (see Ali et al. 1984; Riley 1986). The body length of the good preserved condition specimen of $R$. gigliolii is $9.5 \mathrm{~mm}$. Other characters of the examined material are: abdomen without distinct annuli; cephalothorax trapezoidal, slightly wider than abdomen (Fig. 1a); hooks simple, sharp, anterior hook with $\mathrm{AB} 158 \mu \mathrm{m}$ and BC $106 \mu \mathrm{m}$; posterior hook with $\mathrm{AB} 179 \mu \mathrm{m}$ and BC of $129 \mu \mathrm{m}$ (Fig. 1b); apical and dorsal papillae present and prominent; copulatory spicule is strongly curved and flares gradually into a trumpetshaped base; anus ventral; caudal papillae present.

Amphisbaenidae is well represented in Brazil, with four genera (Amphisbaena, Anops, Bronia, and Cercolophia) and approximately 44 described species (Barros-Filho \& Valverde 1996). Parasitological surveys for identifying the most common endoparasites of these reptiles have not been conducted in detail. The basic food items of amphisbenids include insects such as termites and ants (personal observations). These arthropod food items should be the main transmission vehicles for pentastomid parasites (Ali et al., 1984, 1985).

\footnotetext{
Acknowledgments - Thank you to FUNCAP, Fundação Cearense de Apoio ao Desenvolvimento Científico e Tecnológico, for the research grant (Ref. 943/03 - Edital 003/03) and scholarship of Felipe Silva Ferreira. Regards to CNPq, Brazilian National Research Council for a scholarship to Samuel Vieira Brito and a productivity fellowship to Martin Lindsey Christoffersen. Appreciation to IBAMA, Brazilian Institute for the Environment and Natural Resources, for the permission to collect samples from preserved areas (080/04 - RAN/ IBAMA Processo 02007.001009/04-73). We also thank one anonymous reviewer for valuable suggestions and criticisms on the manuscript, and to Prof. Dr. Jörn Seemann (URCA) for revising the English version of the text.
}

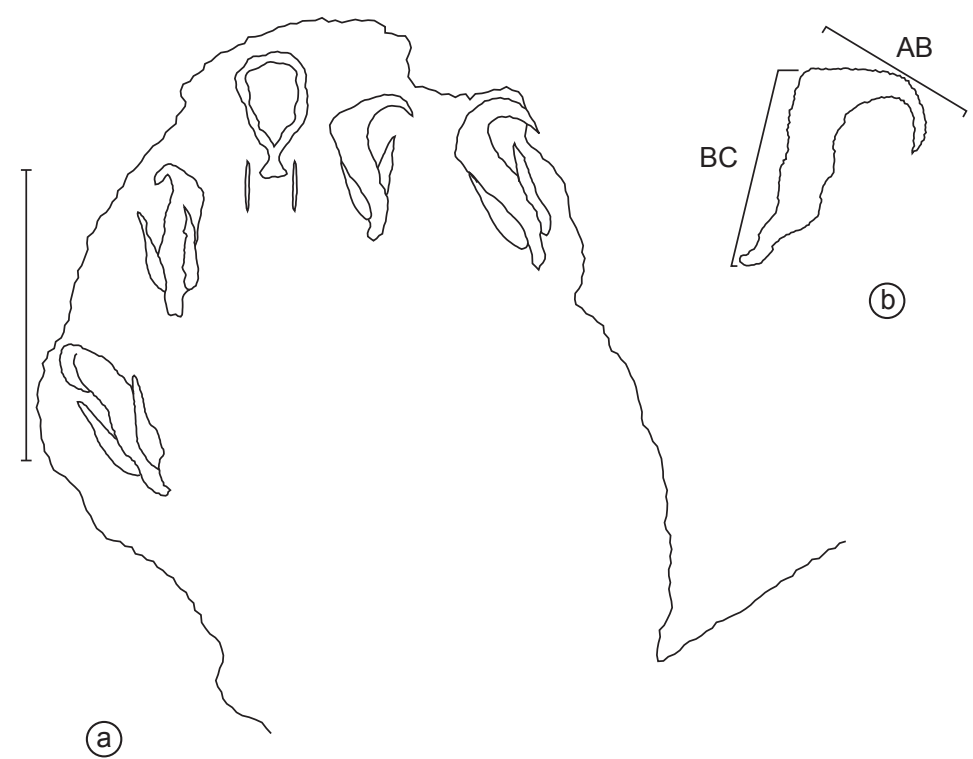

Fig. 1 - a) Details of the cephalothorax of Raillietiella gigliolii male (LZ-URCA 0101) viewed ventrally (scale bar = $0.5 \mathrm{~mm}$ ); and b) Hook dimensions measured: $\mathrm{AB}$, blade length and $\mathrm{BC}$, shank length. 


\section{REFERENCES}

ALI, J. H., RILEY, J. \& SELF, J. T., 1984, A revision of the taxonomy of pentastomid parasites (genus Raillietiella Sambon, 1910) from American snakes and amphisbaenias. Syst. Parasitol., 6: 87-97.

ALI, J. H., RILEY, J. \& SELF, J. T., 1985, A review of the taxonomy and systematics of the pentastomids genus Raillietiella Sambon, 1910 with a description of a new species. Syst. Parasitol., 7: 111-123.

ALMEIDA, W. O. \& CHRISTOFFERSEN, M. L., 1999, A cladistic approach to relationships in Pentastomida. $J$. Parasitol., 85(4): 695-704.

ALMEIDA, W. O. \& CHRISTOFFERSEN, M. L., 2002, Pentastomida, pp. 187-202. In: J. Morrone \& J. LlorenteBousquets (eds.), Biodiversidad, Taxonomía y Biogeografía de Artrópodos de México: Hacia una síntesis de su conocimiento, $3^{\circ}$ vol. 690p. Universidad Nacional Autónoma de México, México.

AURICCHIO, P. \& SALOMÃO, M. G. (Orgs.), 2002, Técnicas de coleta e preparação de vertebrados para fins científicos e didáticos. Instituto Pau Brasil de História Natural, São Paulo, 348p.

BARROS-FILHO, J. D. \& VALVERDE, M. C. C., 1996, Notas sobre os Amphisbaenia (Reptilia, Squamata) da Microrregião de Feira de Santana, Estado da Bahia, Brasil. Sitientibus, Feira de Santana, 14: 57-68.
BUSH, A. O., LAFFERTY, K. D., LOTZ, J. M. \& SHOSTAK, A. W., 1997, Parasitology meets ecology in its own terms: Margulis et al. revisited. J. Parasitol., 83: 575-583.

DIAS, E. J. R., VRCIBRADIC, D. \& ROCHA, C. F. D., 2005, Endoparasites infecting two species of whiptail lizards (Cnemidophorus abaetensis and C. ocellifer; Teiidae) in a restinga habitat of northeastern Brazil. Herp. J., 15: 133-137.

MOTTA, C. S. \& GOMES, D. C., 1968, Sobre um novo gênero e uma nova espécie de Cephalobaenidae (Linguatulida, Cephalobaeniformia). Atas Soc. Biol. Rio de Janeiro, 12(1): 7-9.

REGO, A. A., 1983, Pentastomídeos de répteis do Brasil: Revisão dos Cephalobaenidae. Mem. Inst. Oswaldo Cruz, 78(4): 399-411.

RILEY, J., 1986, The biology of pentastomids. Adv. Parasitol., 25: 45-128.

VANZOLINI, P. E., 2002, An aid to the identification of the South American species of Amphisbaena (Squamata, Amphisbaenidae). Papéis Avulsos Zool., 42(15): 351-362.

VANZOLINI, P. E. \& PAPAVERO, N., 1967, Manual de coleta e preparação de animais terrestres e de água doce. Departamento de Zoologia-USP, Secretaria da Agricultura do Estado de São Paulo, 223p.

VRCIBRADIC, D.; ROCHA, C. F. D.; BURSEY, C. D. \& VICENTE, J. J., 2002, Helminth communities of two sympatric skinks (Mabuya agilis and Mabuya macrorhyncha) from two 'restinga' habitats in southeastern Brazil. J. Helminthol., 76: 355-361. 
